\title{
Research Article: Performance evaluation of mango harvesting techniques
}

\author{
VIRESH KUMARGOUD, S. JAVARE GOWDA, S.K. KARTHIK AND \\ G.V. MOHITHKUMAR
}

Article Chronicle:

Received :

14.07.2017;

Accepted :

29.07.2017

\section{KeY Words :}

Performance evaluation, Mango harvesting, Alphonso, Totapuri, Pre-harvest damage
SUMMARY : Keeping the quality of mango fruits is a varietal character; it depends to a great extent on the harvesting techniques. The field performance of an Indian Institute of Horticultural Research (IIHR) harvester, a local harvester, tree shaking and hand picking with and without pedicel were compared for cultivars Alphonso and Totapuri mangoes. In case of Alphonso an average man could harvest 428, 400, 232, 285 and 329 fruits per hour from 3-5m high trees using above harvesting techniques, respectively. While for Totapuri, the corresponding values were 385, 344, 178, 92 and 170 fruits per hour the pedicel length of both Alphonso and Totapuri mangoes harvested were 1.27, 0.31, 0.41, 0.95 and $0.00 \mathrm{~cm}$. The average shelf-life was 11.6, 9.0, 5.66, 12.0 and 10.5 days in case of Alphonso and 13.3, 11.0, 7.0, 14.0 and 12 days in Totapuri. IIHR harvester was found to be more feasible and may easily be popularized amongst the mango growers. The presence of pedicel could control the sap oozing and lateral infection while increasing the shelf-life and reducing the damage $(6.4 \%)$ to the fruits. The operating cost of harvesting was reduced (Rs. 85/tonne for Alphonso and Rs. 75/tonne for Totapuri) as compared to other harvesting techniques. The cost of IIHR harvester is about Rs. 50 .

How to cite this article : Kumargoud, Viresh, Gowda. S. Javare, Karthik, S.K. and Mohithkumar, G.V. (2017). Performance evaluation of mango harvesting techniques. Agric. Update, 12 (TECHSEAR-4): 1135-1137; DOI: 10.15740/HAS/AU/12.TECHSEAR (4)2017/1135-1137.
Author for correspondence :

\section{VIRESH}

KUMARGOUD

Department of

Agricultural Engineering,

University of

Agricultural Sciences,

G.K.V.K., BENGALURU

(KARNATAKA) INDIA

Email: vkgouda@

gmail.com

See end of th e article for

authors' affiliations 